\title{
Higher Education and Prospects of Graduates' Employability in Tanzania
}

\author{
Ambrose T. Kessy \\ Department of Political Science and Public Administration, University of Dodoma, PO Box 259, Dodoma
}

\begin{abstract}
This paper is about the challenges of employment for graduates of the Higher Education Institutions (HEIs) in Tanzania which has been a serious issue of concern for both the students, parents, universities, the government, and the public. With the rapid expansion of higher education in Tanzania, there is a widely shared concern that graduates face substantial difficulties in the job search and are often forced to accept unfavourable early employment. This article focuses on the relationship between higher education and the employability of graduates. It draws on statistics and a critical review of the literature. Employability of graduate students has been understood as a collection of capacities or achievements, which constitute a necessary but not sufficient condition for getting employed. Using Tanzania as a case study, the paper, therefore, analyses the extent to which the HEIs in the country do foster competencies relevant for employment and work, and the extent of readiness of these institutions in fostering more "employable" competencies of their graduates.
\end{abstract}

Keywords: higher education; employability; university governance, university of the future; labour market

DOI: $10.7176 / \mathrm{JEP} / 11-9-19$

Publication date: March $31^{\text {st }} 2020$

\section{Introduction}

Employment for graduates of institutions of higher education in Tanzania has become a serious issue of concern for both the students, parents, the universities, the government, and the public. Tanzania has experienced a rapid expansion of higher education, which has resulted in a widely shared concern that graduates face substantial difficulties in the job search. These students have to accept unfavourable early employment, and even might be regarded a lost generation in the long run (Inter-University Council for East Africa, 2014; Mushi, 2013; Mwita, 2018; Ngirwa, Euwema, Babyegeya, \& Stouten, 2014). A previous study by Ndyali (2016) explored the importance of higher-level business education human resources development for youth empowerment and national development in Tanzania. It explored these issues four years ago on why large numbers of graduates remain jobless for a long time after graduation and how the universities can assist in training skilled business graduates for the Tanzania economy. This study and others conducted on Tanzania, (Kalufya \& Mwakajinga, 2016; Mpehongwa, 2014; Mwita, 2018) have mainly focused on the supply side with little attention paid on demand questions in the labour market for tertiary education.

This state of affairs calls for analysis and a reconsideration of the quantitative-structural relations between higher education and the world of work (Teichler \& Jung, 2016). This has also transcended to series of questions regarding how do student numbers and the composition of the student body develop according to fields of study, types of study programs and institutions, and how should they develop. It is also necessary to reconsider what study programs and other support institutions of higher education lend to their students. In other words, a more practical question will be about the extent do institutions of higher-education foster competencies relevant for employment and work, to what extent should these institutions care about fostering more "employable" competencies of their graduates. Relatedly to the above, the other most prominent concern is also on the extent to which the higher learning institutions have transformed their internal organization structures and programmes to provide services that help students in the process of transition to employment.

Undeniably, the relationship between higher education and employment of graduates is a major theme that is relevant both for academics, researchers and practitioners in the area of higher education (Kalufya \& Mwakajinga, 2016; P. Knight \& Yorke, 2004; Mwita, 2018). This has called for a clear understanding of the impact of higher education in the labour market. The education experts have also expressed some concerns about the and the rate of employment of the most highly qualified segment of the labour force (Schomburg \& Teichler, 2006). As Anderson (2017) argues, graduate employability has become a thorny issue in the future economy of Tanzania. Some factors which have been mentioned as the leading cause of this problem include the lack of skills in business training, emphasis on the public sector, unattractive agricultural sector, and inadequate labour information on youth employment (Ndyali, 2016)

This paper is organized into seven sections. The first section is the introduction, followed by section two, briefly describe the methodology of this study. Section three engages with the literature on the higher education and employability of graduates. The fourth section assesses trends in students' admission to higher learning institutions in Tanzania. The fifth section of the paper tries to discuss the main challenges facing the universities in general and how these could be addressed. Part six links issues of transformation and employability of the 
graduates. Section six attempts to discuss the university of the future and the challenges ahead. Section six sums up the key issues of the way forward of higher education and employment in Tanzania followed by the final section which is the conclusion with some recommendations advanced.

\section{Methodology}

The study used a mixed approach where qualitative and quantitative data were used. The data collection methods used in this study involved largely a documentary review. Documents were included in this data collection based on their ability to contribute to the themes of higher education and employability and university governance such as published reports and articles. These documents provided a perspective on the analysis of higher education in Tanzania, challenges of employability of the graduates and universities governance.

\section{Higher Education and Employability: Some Theoretical Debates} 3.1 The Relationship between Higher Education and Employability

Employability of graduates has been a subject for discussion for a substantial number of years. There has been a growing interest on the number of graduates getting jobs after their graduation with some statistics showing that the number of those who get jobs is rapidly declining (Anderson, 2017; Kalufya \& Mwakajinga, 2016; Schomburg \& Teichler, 2006; Vavrus, 2005). Kalufya and Mwakajinga (2016) argue for example, that the challenge of employability for graduates is linked to several reasons, including the failure of graduates to meet the current labour market expectations. While it is not the primary purpose of this article to engage with the definitions of impalpability, it is worth noting that the term has been defined in many ways in the literature. For example, Yorke (2006) sees employability as a collection of capacities or achievements, which constitute a necessary but not sufficient condition for the gaining of employment. In other words, employability refers to "a graduate's achievements and his/her potential to obtain a 'graduate job', and should not be confused with the actual acquisition of a 'graduate job' (which is subject to influences in the environment, a major influence being the state of the economy"(Yorke, 2006, p. 2). The works of the author's previous work also caution the reader on the confusion between employability and employment rate. He argues further that employability should not be confused with employment rates. Employment rates are "at the mercy of the vicissitudes of the labour market"(Yorke, 2004, p. 410). This is also echoed by Stiwne and Alves (2010, p. 35) who argue that graduate employability should not be "the same as graduate employment rates' and instead should be defined as 'suitability for graduates' employment".

Research has also proven that academic qualifications such as degrees, diploma or certificates are merely the 'first tick in the box' (Kalufya \& Mwakajinga, 2016, p. 52). In this regard, it is only the graduates who have exhibited attainment beyond the degrees that employers look for (Hugh-Jones, 2008). The implicit in the definitions of employability is the assumption that HEIs can provide both the students with knowledge and skills that can be applied in academic and non-academic environments (Stiwne \& Alves, 2010).

The link between higher education and employability has been extensively debated in the literature (Fahimirad, Nair, Kotamjani, Mahdinezhad, \& Feng, 2019; Fosu \& Boateng, 2013; Idaka, 2013; Vincent \& Robert, 2019). The literature sees education as an opportunity for someone to be employed after graduation(P. Knight \& Yorke, 2004). For example, since the 1960s. a considerable number of studies have been published that describe the relationships between education and employment embedded in the concept of human capital. In this perspective, one of the fundamental functions of education is seen as the preparation of people to meet the needs of the labour market(Cai, 2013; Msigwa, 2016; Schomburg \& Teichler, 2006). This being the case, employers typically pay less importance to academic credentials and instead pay more importance to personal attributes and skills of the graduates especially when there is a high supply of graduates in the market (Stiwne \& Alves, 2010). For example, in Nigeria, the biggest challenge is graduate unemployment that is not related to the unavailability of jobs, but the lack of the employability skills by the graduates (Nwajiuba, Igwe, Akinsola-Obatolu, Ituma, \& Binuomote, 2020). From this discussion, it appears that the HEIs are often blamed for producing graduates who fail to meet employment demands in the labour market.

\subsection{Higher Education System in Tanzania}

Higher education in Tanzania refers to the scope of knowledge and skills imparted within the tertiary level .of education(The United Republic of Tanzania, 1999). Universities, as the highest-level of institutions, are dedicated to the professional and intellectual development of mankind and society and therefore are expected to concentrate on research, teaching and public service or consultancy. Tanzanian's education system has grown from a relatively simple to a complex one since independence. The education system has grown from only one institution of higher education (a university college) in 1961 to more than 48 in 2019 (The Controller and Auditor General, 2019; The United Republic of Tanzania, 1999). However, many of these have been duplicating one another's course programmes and awards, seeking to assume a status above what they are awarding qualifications and titles above their capacities. Generally, the Higher Education Institutions (HEIs) in sub-Saharan Africa sprung up and acquired 
prominence in the $1950 \mathrm{~s}$ and $1960 \mathrm{~s}$ during the era of at the peak of the movement for political independence. There were many critical issues that HE had to wrestle with as it was trying to maintain momentum and a respectable presence in sub-Saharan Africa. These issues revolved included the relevance of universities' curricula, high unit costs and the ivory tower mentality exhibited by some HE graduates (Mkude, 2011).

Higher education in Tanzania is managed by the Ministry of Education, Science and Education (MoEST). The Higher Education Division under the MoEST oversees the quality and effective development of higher education subsector policy and resource mobilisation for enhanced access, quality, and equity in higher education by performing the following:

- To promote high quality and internationally competitive teaching and learning, research, and innovation;

- To provide inputs in developing, monitoring, evaluating, and reviewing the implementation of Higher Education policies;

- To initiate, monitor and evaluate the implementation of the ministry's Higher Education development plan, programmes and projects;

- To catalyze the development of world-class higher education including advising on the alignment of higher education to the developmental needs of the society;

- To liaise with the Tanzania Commission for Universities as well as the National Council for Technical Education and other professional bodies and thereby facilitate the development of quality and relevant higher education-related skills-sets in the country;

- $\quad$ To liaise with the Inter-University Council for East Africa and other regional bodies and thereby promote and sustain Regional Integration and International Cooperation on Higher Education;

- To promote public awareness on the functions and roles of Higher Education subsector;

- $\quad$ To prepare and submit periodic reports as required from time to time; and

- To initiate and carry out a skill audit to facilitate training plans ${ }^{1}$

These functions give considerable statutory powers to the Higher Education Division in Tanzania to run university education. However, looking critically at these functions, several questions pop up: From where to where? What does it want to achieve? Are these transformations leading to more employability of graduates or just employment? Who is really in charge of these reforms -is the Ministry, HEIs, the students, donors, private sector, or who else? Who defines the scope and content of education transformation? These are some of the critical questions that will be guiding the rest of this paper.

\section{Analysis of the Supply and demand in the labour market for tertiary education graduates 4.1 Trends in students' admission in tertiary education by major categories of disciplines in Tanzania}

Tanzania is one of several developing countries which have carried out massive investment in the education sector with a view of expanding enrolment at all levels of the education system. Enrolment in higher education is increasing as more universities, and other tertiary training institutions are established or expanded. For example, admission in tertiary education reached 40,479 in 2009/2010 and increased to 44,715 in 2012/13, an increase of $10.5 \%$ in just three years (Mushi, 2013). As at $30^{\text {th }}$, June 2018, the admission had increased to 69,539 in 2016/2017 but slightly decreased to 63,737 in 2017/2018 (The Controller and Auditor General, 2019).

\begin{tabular}{|c|l|l|l|}
\hline SN & Ownership & $\mathbf{2 0 1 7 / 2 0 1 8}$ & $\mathbf{2 0 1 6 / 2 0 1 7}$ \\
\hline 1. & Public Universities & 50,576 & 44,732 \\
\hline 2. & Private Universities & 13,161 & 24,807 \\
\hline & TOTAL & 63,737 & 69,539 \\
\hline
\end{tabular}

Table 1: Harmonized and approved admission by TCU for the 2016/2017 and 2017/2018

Source: The Controller and Auditor General (2019)

This sheer number of higher learning institutions in Tanzania implies that the supply side is significant in terms of graduates which may leave the demand side unable to accommodate the pressure. However, while the data in Table 1 shows that there has been an expansion in education in general and university education, this is perhaps seen in many quarters of government as a symbol of development. It should be noted, however, that the numbers of student enrolment and institutions are very much cherished by politicians who use the figures as an indicator for significant progress a country has made since a particular government is in power (Sifuna, 1998). Nonetheless, there is hardly mention of the quality of education offered at such institutions and the number of graduates who are employed.

\subsection{The Supply Side Question: An Overview of Employability of University Students}

Employability for university graduates has become a subject for discussion for several years. However, there has been a growing interest in it over the last decade. This has been attributed to the fact that in the current competitive

\footnotetext{
${ }^{1}$ http://www.moe.go.tz/en/structure/division/higher-education.html accessed on 16.11.2019
} 
environment, it makes sense to get on the first step of the career ladder, despite the challenges involved. In this regard, graduates need to demonstrate over and above their degree, attainment the importance of the skills and attributes that they need possess (Kalufya \& Mwakajinga, 2016). In the same vein, the Tanzania Development Vision 2025 identifies science and technology as pillars of innovation and competitiveness. However, the paper argues that skills mismatch with the vision may prevent the country from attaining a competitive knowledge economy. It recommends that incentives offered to science students at tertiary education should be extended to secondary education, where students make critical career decisions (Mpehongwa, 2014). While this problem had been seen serious for secondary leavers, it has moved up to affect the graduates as well.

The supply of labour force by the higher institutions is not questionable, and it has been increasing year after year. For example, institutions with a certificate of the provisional license which were registered and allowed to run academic and research activities as at $30^{\text {th }}$ June 2018 were 48 (See Table 2)

\begin{tabular}{|c|c|c|c|c|c|c|}
\hline \multirow{2}{*}{ Type of Institution } & \multicolumn{2}{c|}{ Public } & \multicolumn{2}{c|}{ Private } & \multicolumn{2}{c|}{ Total } \\
\cline { 2 - 7 } & $2017 / 18$ & $2016 / 17$ & $2017 / 18$ & $2016 / 17$ & $2017 / 18$ & $2016 / 17$ \\
\hline Fully fledged Universities & 12 & 12 & 22 & 22 & 34 & 34 \\
\hline Constituent Colleges & 2 & 2 & 12 & 12 & 14 & 14 \\
\hline Centres and Institutes & 4 & 4 & 16 & 17 & 20 & 21 \\
\hline TOTAL & 18 & 18 & 50 & 51 & 68 & 69 \\
\hline
\end{tabular}

Table 2: University level Institutions operating in Tanzania by Status and ownership

Source: The Controller and Auditor General (2019)

While it may be easy to get the number of registered higher institutions and the number of graduates from these institutions, the exact number of those who employed after their studies is somewhat tricky. One of the few attempts to address this problem is the study commissioned by the Ministry of Education and Vocational Training in 2013. This study reported that the estimated total number of graduates of tertiary education joining the labour market every year for the period of 2010/2011 was 28,032 (Mushi, 2013). However, this analysis was only worked out as an average of the two years for which data were available. The study noted that this number is not static because the tertiary education sub-sector is expanding every year as indicated.

Further analysis of the composition of the supply side by the major categories of disciplines showed that the leading category in terms of supply in the labour market was Education; followed by Law \& Social Sciences, and Business Management \& Administration. Categories with a relatively small supply of graduates were Natural Sciences, Agriculture, Engineering Sciences and Medical Sciences. This study also cautioned that the supply side was slightly overestimated by not being able to exclude graduates who were already employed at the time of admission or got employed during their training. However, this was a marginal proportion of the total number of graduates of tertiary education in Tanzania. Notwithstanding, the study acknowledged its inability to get hold of precise information for dealing with returning graduates from foreign institutions and those getting employed before enrolling for, or completing tertiary education.

Employment is an integral part of the economic, social, and environmental development process and procedure of any country. Employment provides financial freedom and decision-making power in society. A country needs to absorb most of the existing labour force to boost the economy. On the other hand, the unemployed workforce is a wastage of the current opportunities the economy holds. High levels of employment in any country is crucial as it helps to keep citizens away from the involvement of unlawful activities((NBS) National Bureau of Statistics, 2018).

Efforts to improve technical and vocational education need to reflect the demands of the labour market. Analysis of unemployed youths in respect of the level of education aims at showing how employable youths are, given their education. It also helps policymakers and skills providers to review their curricula and allocate relevant resources for labour market demand-driven skills (National Bureau of Statistics, 2014). Ironically, education providers typically are not held accountable for employment outcomes. This being the case, it is no wonder that they do not have a clear view of the challenges of finding a job their graduates face. Generally, most of the higher education providers surveyed by the Inter-University Council for East Africa could not estimate the percentage of their graduates were employed after graduation, and many of those who did offer a guess got it wrong. For example, three-quarters of the providers believed that most of their graduates $(74 \%)$ found work in three months or less, while those who were somehow optimistic said that about $54 \%$ found employment after graduation. The survey findings further indicate that persons graduating at any one time were employed by the end of three years of graduation (Table 3 ) 


\begin{tabular}{|l|l|l|l|l|l|l|}
\hline \multirow{2}{*}{ Group of Respondents } & \multicolumn{5}{|c|}{ \% of Graduates by Period } \\
\cline { 2 - 7 } & $\leq 3$ Months & $\leq 6$ Months & $\leq 9$ Months & $\leq 1$ Year & $\leq 2$ Years & $\leq 3$ Years \\
\hline Young People & 53.7 & 10.4 & 5.5 & 2.8 & 16.9 & 10.5 \\
\hline Education Providers & 73.5 & 20.4 & 3.9 & 2.2 & & \\
\hline Employers & 58.3 & 15.7 & 18.9 & 5.3 & 1.8 & \\
\hline Policy Makers (Government)* & 13.6 & 9.4 & 3.9 & 8.3 & 3.3 & 4.8 \\
\hline
\end{tabular}

Table 3: Perception of Population of Graduates Finding Jobs after Graduation

Source: Inter-University Council for East Africa (2014)

The data in Table 3 may be somewhat outdated, but the problem of getting more updated data is compounded by the lack of a single entity dealing with monitoring of labour information in Tanzania. For example, while the Tanzania Employment Service Agency (TAESA) was established to, among other things, monitor and record trends in jobseekers in the labour market for graduates, its performance is somewhat unsatisfactory. TAESA was meant to be a service centre for which job seekers register themselves for opportunities in the labour market. However, various studies have shown that not all job seekers register (Mushi, 2013). On average, the total number of graduates from tertiary education who registered with TAESA for the period of 2011/2012 was 759 every year for the following five years which was only about $3 \%$ of the total number of the graduates. According to Mushi (2013), of all the job seekers registered by TAESA for the last five years before 2011, the majority came from the Business Management \& Human Resource and Administration category (55\%); followed by Law and Social Sciences, Humanities \& Art. The categories with relatively the least proportion were Extractive Industry and Health Sciences. The study concluded that although about $45 \%$ of graduates of tertiary education came from Education, they find it easy to get a job compared to graduates in other disciplines (Mushi, 2013).

Recent findings from the NBS National Bureau of Statistics (2018) also shows that males with tertiary education had a more substantial number of newly recruited employees amounting to 8,279 (23.7 per cent) compared to females workers with 4,559 which is equivalent to 13.2 per cent. The findings further show that there is a significant difference in the numbers of newly recruited employees among males and females having Teacher's education or College whereby males are having a more significant number (6,443 employees) compared to females (4,442 employees).

\begin{tabular}{lrrrrr}
\hline Level of Education & Number & $\begin{array}{r}\text { Male } \\
\text { Percent }\end{array}$ & $\begin{array}{r}\text { Female } \\
\text { Number }\end{array}$ & $\begin{array}{r}\text { Percent } \\
\text { Total }\end{array}$ \\
\hline Tertiary University & 8,279 & 23.7 & 4,559 & 13.2 & 12,838 \\
Tertiary Non University & 3,209 & 9.2 & 3,216 & 9.3 & 6,425 \\
Teacher's Education/College & 6,443 & 18.4 & 4,442 & 12.8 & 10,885 \\
Vocational Education & 5,802 & 16.6 & 6,703 & 19.3 & 12,505 \\
Secondary Education: A-level & 756 & 2.2 & 558 & 1.6 & 1,314 \\
Secondary Education: O-level & 4,815 & 13.8 & 3,807 & 11.0 & 8,622 \\
Primary Education & 5,671 & 16.2 & 11,379 & 32.8 & 17,050 \\
Total & $\mathbf{3 4 , 9 7 5}$ & $\mathbf{1 0 0}$ & $\mathbf{3 4 , 6 6 4}$ & $\mathbf{1 0 0}$ & $\mathbf{6 9 , 6 3 9}$ \\
\hline
\end{tabular}

Table 4: Number of Newly Recruited Employees by Sex and Level of Education, Tanzania Mainland, 2015/16

Source: NBS National Bureau of Statistics (2018)

Borrowing from other countries, Tanzania could rethink on the need to establish a government agency which will be dealing enhancing student employability similar to the case of the Higher Education Funding Council for England which sponsors national work for raising awareness on what higher education should be doing to help the graduates since employability is becoming a global issue (P. Knight \& Yorke, 2004)

\subsection{The Demand Side Question: Unemployment Rate Challenges}

The unemployment rate is the best-known labour market measure. It is also one of the most used by media in many countries. The unemployment rate is a useful measure of the underutilization of the labour supply. Similarly, the analysis of unemployment helps the policymakers allocate relevant resources for labour market demand-driven skills and for the higher learning institutions to review their curricular. Thus, efforts to improve technical and vocational education need to reflect the demands of the labour market (National Bureau of Statistics, 2014). Recent results from the projections by the National Bureau of Statistics reveals that the unemployment rate in Tanzania has been decreasing from 10.3 per cent recorded in 2014 to 9.7 per cent in 2018 . This results may imply that the economy has been doing well in absorbing the ever-increasing labour force in the country ((NBS) National Bureau of Statistics, 2018) (Figure 2) 


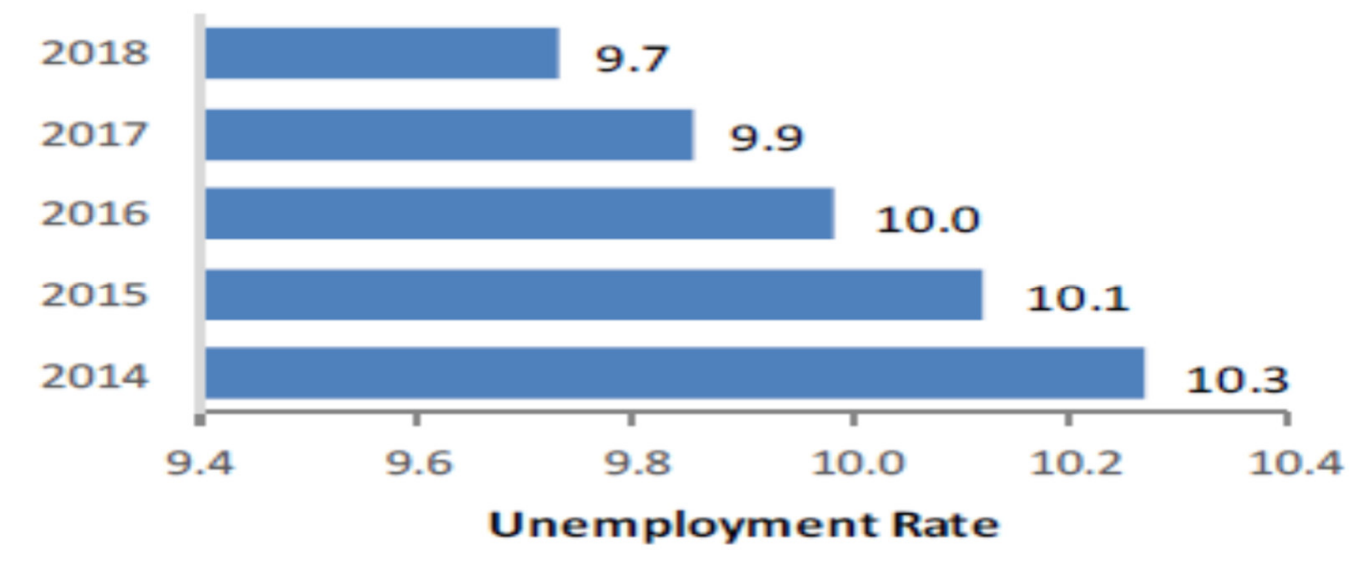

Figure 2: Unemployment Rate in Tanzania Mainland

Source: (NBS) National Bureau of Statistics (2018)

While the rate of unemployment has been slightly decreasing from 2014, the problem of unemployment and underemployment in Tanzania is still a critical issue, especially for new graduates. This is well documented by National Employment Policy (2008) which notes that unemployment has become serious in the country and should be regarded as a major national development challenge with ramifications for economic welfare, social stability and human dignity (United Republic of Tanzania, 2008). This problem is also echoed by the study by Mwita (2018) which used a sample of 100 human resource practitioners to assess their perception of Tanzania graduate employability. The study found that HR practitioners consider Tanzania graduate as average. The same survey found that $52.6 \%$ of Human Resource practitioners disagree that Tanzania graduate quality is improving; while $56.6 \%$ believe that Tanzania graduate is not competent enough to compete for jobs in the East African labour market. Nonetheless, other studies have shown that the higher youth unemployment rate in the country does not necessarily mean that there is the absence of jobs but rather the inability of youth to acquire the available jobs (Ndyali, 2016).

\section{Challenges and Factors Facing Institutions of Higher Education in Tanzania}

Complaints from the industry have been raised on the skills gap, for example, in relation to curricula design that is production-led, based on staff experience, interests and availability, rather than necessarily preparing graduates for the industry-employment market (Mbise, 2016). This problem has been linked to the fact that most of the undergraduate and graduate programmes at the universities are too theoretical and do not expose the students to practical experiences. For example, the design of curriculum and syllabi for most of the universities in Tanzania is reflective of the established examination system where a student is asked to do a question paper at the end of a semester (Anderson, 2017; Kalufya \& Mwakajinga, 2016; Ndyali, 2016). This antiquated examination system does not truly test the right skills of the student in the pursuit of theoretical or practical knowledge in real-world situations. Thus, a significant number of Tanzania education stakeholders have argued that the education offered is not adequately geared to integrate the individual into the strong competitive labour market (Mwita, 2018).

Inadequate financial and qualified human resource is the greatest challenge facing almost all universities in Tanzania. Most of the academic staff and non-academic staff are of lower profile holding a certificate, diploma, advanced diploma, bachelor, and a master degree. This is also worse for the private universities which have inadequate human resources, physical resources, fiscal resources, and learning facilities. As a result, these inefficiencies in both financial and human resources appear to have diminished quality; as a result, graduates are unable to deliver at workplaces, and thus unemployment rates continue to increase at unprecedented scale (Makulilo, 2012)

Leadership and governance for higher education institutions is another challenge. University governance is one of the key elements for improving the quality of the graduates. Some of the notable characteristics of successful world-class universities are: leadership, government policy, funding, the ability to focus continually on a clear set of goals and institutional policies, development of a strong academic culture and quality of the academic staff (Jaramillo \& Hafedh Zaafrane, 2014, p. 9).

Similarly, as the universities embark on producing leaders for the 21 st Century, three essential attributes (space, vision and empowerment) must also be taken into account: a) an understanding that students bring talent and creativity to the field of efficiency especially if they are provided with a venue to be inspired and educated; b) the ability to work out a coherent and clear vision; and c) the ability to articulate this vision and to empower every other person to actualize it (Inter-University Council for East Africa, 2014). Other challenges include the 
governance Structure in the Universities. The dominant ideals of the organization and governance of universities have changed over the last few decades. This means that the Universities of the Future is expected to be informed by two broad sets of ideas about university governance. The first is a republic of scholars and second regards the university as a stakeholder organization (Bleikliea \& Kogan, 2007). The problem of governance is, therefore, the location of authority to resolve these issues: internal and external. This is where some considerations about power relations between the central administration and the lower levels of governance. Structural reorganizations occurred frequently. Each structural change has implications on the way the central authority of the universities devolves, delegate or deconcentrate powers to the lower units.

According to Bradshaw and Fredette (2009), governance of universities is conceived of as the reframing, challenging, and questioning of the leadership vision and interpretation of reality. Senates which are responsible for making strategic decisions about the universities are seen other governing bodies which can be working at three levels simultaneously: making strategic decisions (approval/rubber-stamping role), shaping these decisions (through consultation or testing ideas, raising questions, challenging assumptions, giving advice, and encouraging learning), and developing the context and conductor strategy (constructing arenas in which strategy is debated). Nonetheless, there is no one single model or "one size fits all" approach to university governance. What is important is to acknowledge a particular model being used and to assess if it is the best model for a particular institution, given its political, social and economic contexts(Jaramillo \& Hafedh Zaafrane, 2014).

Universities governance can, therefore, be identified with other different governance modes: quasi-market, network steering, interactive governance, multi-level and multi-actor governance (Flórez-Parra, López-Pérez, \& López-Hernández, 2017). The key point about the dispersion of these powers from the university's central administration to the lower levels of governance relates to how they are driven by the new directions which call for networks of research and learning; internationalization; information and communication technologies; competitiveness and their attempt to create market niches; and commercialization.

\section{What is Next? -The University of the Future: Transforming University Governance and teaching and learning methods}

The challenges discussed above call for rethinking about the future of $\mathrm{HE}$ and governance of in general. As Cross and Ndofirepi $(2017$, p. 3) argue, there are still no good African universities which serve the needs and equip graduates with the knowledge, skills and attitudes required for transforming their societies. According to Ernst \& Young LLP and Federation of Indian Chambers of Commerce and Industry (2018), universities need to be prepared for both unprecedented challenges, including available ample opportunities for innovation. As universities move towards 'knowledge economy', the developing countries are likely to benefit more in development. In this case, in the coming years, universities will have to transform their traditional status working alone as academic institutions when higher education becomes more integrated into the economy. This is also to argue that as globalization and technological advances maintain momentum, HE policy change to encourage universities to become more global and satellite-based.

To advance the movement towards University of the future, Ernst \& Young LLP and Federation of Indian Chambers of Commerce and Industry (2018) uses the analogy of Education 3.0. and 4.0. Education 3.0. is the traditional or current status of the universities' governance and operations, while Education 4.0. is the envisioned university of the future. They call upon the universities to move from Education 3.0 to Education 4.0 in terms of improving the ways of teaching students and attaining learning objectives using the power of ICT facilities. According to EY and FICCI (2018) technology has helped in creating personalized learning, flexibility and the comfort of distance learning at an unprecedented pace and appropriate time (See Figure 1)

\begin{tabular}{lll} 
Parameters & Education $\mathbf{3 . 0}$ & Education $\mathbf{4 . 0}$ \\
\hline Faculty & Full-time teachers & $\begin{array}{l}\text { In addition to full time faculty, industry } \\
\text { participants act as part-time faculty for } \\
\text { classroom and online courses }\end{array}$ \\
\hline Curriculum and pedagogy & $\begin{array}{l}\text { Minor flexibility in pedagogy; massive } \\
\text { learning }\end{array}$ & $\begin{array}{l}\text { Subject matter decided by the learner; } \\
\text { personalized learning }\end{array}$ \\
\hline Research & $\begin{array}{l}\text { Transition towards collaborative research } \\
\text { using technology }\end{array}$ & $\begin{array}{l}\text { Ease of data sharing has removed the geo- } \\
\text { graphical barriers to collaboration }\end{array}$ \\
\hline Funding & $\begin{array}{l}\text { Fee-based funding systems at degree } \\
\text { level }\end{array}$ & $\begin{array}{l}\text { Fee-based funding systems in both online } \\
\text { and classroom program }\end{array}$ \\
\hline Infrastructure & $\begin{array}{l}\text { Majority of investment in physical infra- } \\
\text { structure }\end{array}$ & $\begin{array}{l}\text { Investment in technological infrastructure } \\
\text { to support blended learning }\end{array}$
\end{tabular}

Figure 2: Education 3.0. and Education 4.0. Compared

Source: Ernst \& Young LLP and Federation of Indian Chambers of Commerce and Industry (2018) 
Education 3.0. has been criticized for its failure to place the student at the center and focusing on experiential learning. For example, the traditional HE system has been criticized for the following:

- Plateauing enrolment due to limitations on infrastructure and faculty

- Rigid learning structure often forcing students to study programs outside their field of interest

- Inflexible delivery method and schedules with no room to accommodate students with other commitments

- The rising cost of quality, HE increasing the pressure of student debt on learners (Ernst \& Young LLP \& Federation of Indian Chambers of Commerce and Industry, 2018)

The authors, therefore, recommend for HEIs to move to Education 4.0 which has the potential to overcome the constraints of the traditional education system by targeting the new-age learner cohort. This revolution calls for customizable and flexible program structures delivered across technology-enabled and affordable platforms and real-time integration with the industry. It is therefore imperative for HEIs to redefine the education system by enriching the student learning experience, focusing on employability and providing opportunities for research excellence

A significant number of East African countries have introduced far-reaching reforms aimed at improving higher education provision by increasing emphasis on expanded access opportunities while protecting the learners from falling prey to substandard or bogus education providers(Kalufya \& Mwakajinga, 2016; Msigwa, 2016; Ndyali, 2016; Ngirwa et al., 2014; Vavrus, 2005). However, despite these dynamics, the reforms appear not to be radical enough to synchronize the missions of higher education institutions with government priorities as well as meeting the expectations of employers and the society at large (Inter-University Council for East Africa, 2014). The council notes further that while the EAC Partner States aspire to transform into knowledge-based economies in the coming 10-20 years, the pillars for such transformation, namely human resource capacity and a vibrant research and innovation system, continue to remain shaky, and therefore posing formidable challenges to overcome the situation.

Other studies have emphasized the need to strengthen Public-Private Partnerships (PPPs) by redefining the role of the state in providing social services by also providing adequate space for the private sector's role in the provision of education. Mgaiwa and Poncian (2016), for example, argue that the state should focus more on the strategic control, funding, and planning of the education system. Similarly, employers expect graduates to have the technical and discipline competencies from their degrees with the ability of the graduates to demonstrate a range of broader skills and attributes that include teamworking, communication, leadership, critical thinking, problem-solving and often managerial abilities (Kalufya \& Mwakajinga, 2016).

On the other hand, the higher universities need to transform themselves to accommodate these new dynamics of the labour markets. They need, for example; reconsider the way they teach and interact with their students. One far-fetched idea worth considering proposed by J. Knight (2015) is the notion of "edu-glomerates". The idea builds on the recent phenomenon of education hubs, academic cities, or higher education zone. All these bring together a diversity of international and local education providers, including the three generations of international universities and private, professional training establishments.

Moreover, it has been established by some studies that that young people consider online or distance learning to be as effective as traditional modes for enhancing their professional skills. For example, about $62 \%$ of the young people who were asked to indicate the most effective instructional techniques said on the job training is the most effective with about $30 \%$ saying the traditional lecture is the most effective (Inter-University Council for East Africa, 2014) (Table 5)

\begin{tabular}{|c|c|c|c|}
\hline \multirow[t]{2}{*}{ Method of Delivery } & \multirow[t]{2}{*}{ 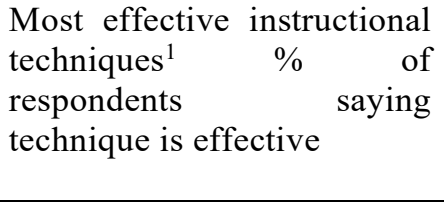 } & \multicolumn{2}{|c|}{$\begin{array}{l}\text { Use of hands-on learning in academic } \\
\text { and vocational institutions }{ }^{2} \quad(\% \\
\text { respondents indicating most hours spent } \\
\text { in learning methodology) }\end{array}$} \\
\hline & & Theoretical & Hands-.on \\
\hline On-the-Job Training & 62 & & \\
\hline Hands- on learning & 58 & & \\
\hline Multimedia & 54 & & \\
\hline Seminars & 46 & & \\
\hline Traditional lecture & 30 & & \\
\hline Online/distance learning & 30 & & \\
\hline Higher Education Graduate & & 6 & 24 \\
\hline Technical and Vocational & & 63 & 37 \\
\hline
\end{tabular}

Table 5: How Young People Prefer to Learn

Source: Inter-University Council for East Africa (2014)

It can be further stressed that rapid changes in industry requirements have increased the gap between what the traditional education universities produce and what the conventional HE provides and what employers now 
demand. This requires a different outlook in terms of balancing the existing mismatch of the existing teaching modalities and the learning needs of different types of students. In other words, the Higher Education Institutions (HEIs) are compelled to offer innovative models of learning, leading to the competency-based learning models. Competency-based learning enables students to progress at an individual pace by allowing them to have their own time to attain proficiency in the relevant required skills. As such this model of teaching allows instructors to have more autonomy to cater for students' diverse needs across the various levels of learning (Ernst \& Young LLP \& Federation of Indian Chambers of Commerce and Industry, 2018).

The pressure for HE and universities' governance to transform is also linked to the increasing rate population growth. It is estimated that by the middle of this century, East African region will have a population of about 300 million people which is twice the current population number (Inter-University Council for East Africa, 2014). This projection will include a population with a workforce of more than 109.3 million people. This implies that for the markets to accommodate this skilled workforce, it would be necessary for governments to increase the number of jobs in the next 35 years and expand the private sector. The recent survey by the Inter-University Council of East Africa shows some alarming trends of three quarters of young people under 25 being unemployed (Inter-University Council for East Africa, 2014). The survey further notes that despite having many people looking for work at the moment, more often than not, employers in the EAC Partner States find it difficult to locate people having the needed skills. This trend is also exacerbated by the growing patterns of population trends as there is already an increased movement of young people away from farms and rural areas to urban areas, implying that about $75 \%$ of the population will be urban residents (Agwanda \& Amani, 2014).

\section{Conclusion}

This paper has addressed the question of higher education transformation and employability for the graduates. The discussed has noted that there is much confusion about the two concepts when it comes to implementation. Graduates now cannot find a direct link between what they studied and the requirements of the labour market. This has been attributed to a sheer number of graduates per year and the capacity of the labour market to absorb them. Some other factors which have been linked to this problem have been of the nature of the higher institutions in which they study where curricular miss out the practical aspects that are needed in the labour market. This mismatch is becoming serious concern for the government, higher institutions, parents, students, and the public. The system theory perspective has provided the link for the reinforcing the feedback loop between the type of students' universities produce and the demands from the labour market which requires the universities to transform themselves in the way they teach, enhancing the quality of their products and establishing some mechanisms for helping students to secure jobs.

However, this paper does claim to have proposed a clear-cut standardized transformed model of higher education or universities' transformation, nor should there be. A standardized approach to transformation would neglect the critical importance of the cultural, social, economic, political, and academic context of where the universities are formed. Nonetheless, one should note that higher education varies from other levels of educational attainment because it is at least geared to direct professional preparation. For example, research and teaching in higher education inspire academics to pursue knowledge for its own sake. On the other hand, students are not trained for specific job assignments because they should be able to reflect, criticise and revamp established professional practice.

\section{Lessons and Recommendations}

There is no doubt that higher education and universities need to change to address the discussed problem of unemployability of the graduates. However, information on the number of students graduating from tertiary education in Tanzania is not readily available from a single source. Neither the information on the number of graduates who are employed after their graduation. The data are so much fragmented even within the respective training institutions. Accordingly, there is a need to establish an effective Tertiary Education Labour Market Observatory (TELMO) system. The observatory system will be used as a centre or unit for collecting and documenting information on labour market outcomes, conducting comprehensive graduate tracer studies and sharing information on labour market with education stakeholders- i.e. students, parents, MoEST, and tertiary education institutions; Ministry of Labour, Employment and Youth Development, Ministry of Finance and Development Partners. Tanzania could also borrow some experiences with regard to Labour Monitoring Information (LMI) for Graduates from other countries such as Nigeria is a good example, where a labour market observatory has been established to address the current challenge in which the graduates (future employees) invest their time and other resources in skills that do not provide them with any optimal advantage on the labour market. Hence, the main concern from the employers had been on the part of additional costs that they have to incur in training fresh graduates so that they can meet with skills levels required to perform specific tasks. This challenge also resulted in increased utilization of expatriate labour and promotion of capital fights. Thus, the National Manpower Board (NMB) was established to collect, process, analyse and deploy LMI for the development of 
sectoral policies including education.

\section{References}

Agwanda, A., \& Amani, H. (2014). Population Growth, Structure and Momentum in Tanzania. In THDR 2014: Background Paper No. 7 ESRF Discussion Paper 61: The Economic and Social Research Foundation (ESRF).

Anderson, G. (2017). Graduates' Perceptions of the Contribution of University Education to Graduate Employment in Tanzania. (Masters of Science in Marketing Management (MSC MKT)). Mzumbe University.,

Bleikliea, I., \& Kogan, M. (2007). Organization and Governance of Universities. Higher Education Policy, 20 , 477-493. doi:10.1057/palgrave.hep.8300167

Bradshaw, P., \& Fredette, C. (2009). Academic Governance of Universities: Reflections of a Senate Chair on Moving From Theory to Practice and Back. Journal of Management Inquiry, 18(2), 123-133.

Cai, Y. (2013). Graduate employability: a conceptual framework for understanding employers' perceptions. Higher Education, 65(4), 457-469. Retrieved from www.jstor.org/stable/23470832

Cross, M., \& Ndofirepi, A. (2017). Knowledge and Change in African Universities (Vol. 1). Rotterdam: Sense Publishers.

Ernst \& Young LLP, E., \& Federation of Indian Chambers of Commerce and Industry, F. (2018). University of the Future Bringing Education 4.0 to life. Retrieved from Delhi, India:

Fahimirad, M., Nair, P. K., Kotamjani, S. S., Mahdinezhad, M., \& Feng, J. B. (2019). Integration and Development of Employability Skills into Malaysian Higher Education Context: Review of the Literature. International Journal of Higher Education, 8(6). doi:10.5430/ijhe.v8n6p26

Flórez-Parra, J. M., López-Pérez, M. V., \& López-Hernández, A. M. (2017). Corporate governance in Colombian universities. International Review of Administrative Sciences, 85(3), 544-565. doi:10.1177/0020852317707331

Fosu, R., \& Boateng, R. E. (2013). The Scottish University Level Entrepreneurship Education Initiative: Lessons for Ghana in Dealing with Graduate Unemployment. Journal of Education and Practice, 4(24).

Hugh-Jones, S. (2008). Are We Giving Employers What They Want? . The Psychologist, 12(12), 1050-1051.

Idaka, I. (2013). Re-engineering University Education for Employability in Nigeria. Journal of Education and Practice, 4(11).

Inter-University Council for East Africa, IUCEA (2014). Report from a Study Establishing the Status of Higher Education Qualifications Systems and their Contributions to Human Resources Development in East Africa.Inter-University Council for East Africa, IUCEA.

Jaramillo, A., \& Hafedh Zaafrane. (2014). Benchmarking university governance in the MENA region. Higher Education Management and Policy, 23(4).

Kalufya, N., \& Mwakajinga, L. (2016). Employability of Graduates from Higher Education Institutions in Tanzania. Institute of Social Work Journal, 1(2).

Knight, J. (2015). International Universities. Journal of Studies in International Education: Misunderstandings and Emerging Models?, 19(2), 107-121. doi:10.1177/1028315315572899

Knight, P., \& Yorke, M. (2004). Learning, Curriculum and Employability in Higher Education. London: RoutledgeFalmer.

Makulilo, V. B. (2012). The proliferation of private universities in Tanzania: Quality compromised? Wudpecker Journal of Educational Research, 1(4), 51 - 66.

Mbise, E. R. (2016). Managing Students'Job Opportunity Expectations in Tanzanian Context. Business Education Journal, 1(2)

Mgaiwa, S. J., \& Poncian, J. (2016). Public-private partnership in higher education provision in Tanzania: implications for access to and quality of education. Bandung: Journal of the Global South, 3(1), 1-21. doi:10.1186/s40728-016-0036-z

Mkude, D. (2011). Higher Education as an Instrument of Social Integration in Tanzania: Challenges and Prospects. Research in Comparative and International Education, 6(4), 366-373. doi:10.2304/rcie.2011.6.4.366

Mpehongwa, G. (2014). Career Choices of University Students in Tanzania and their Implications for Vision 2025. International Journal of Humanities and Social Science, 4(5).

Msigwa, F. (2016). Widening participation in higher education: a social justice analysis of student loans in Tanzania. Higher Education (00181560), 72(4), 541-556. doi:10.1007/s10734-016-0037-5

Mushi, D. P. (2013). Draft Report of the Study on Establishment of Tertiary Education Labour Market Observatory (TELMO) in Tanzania. A Consultancy Report Submitted to the Ministry of Education and Vocational Training

Mwita, K. M. (2018). Tanzania Graduate Employability: Perception of Human Resource Management Practitioners. International Journal of Human Resource Studies, 8(2). doi:10.5296/ijhrs.v8i2.12921

National Bureau of Statistics, NBS. (2014). Integrated Labour Force Survey: Analytical Report. In Tanzania Mainland: The United Republic of Tanzania. 
National Bureau of Statistics, NBS, (2018). Formal Sector Employment and Earnings Survey, 2016: Tanzania Mainland. In: Ministry of Finance and Planning, The United Republic of Tanzania, .

National Bureau of Statistics, NBS. (2018). Labour Market Information in Tanzania, 2018: Employment Projections. In: The United Republic of Tanzania.

Ndyali, L. (2016). Higher Education System and Jobless Graduates in Tanzania. Journal of Education and Practice, $7(4)$.

Ngirwa, C. C., Euwema, M., Babyegeya, E., \& Stouten, J. (2014). Managing change in higher education institutions in Tanzania: A historical perspective. Gérer le changement dans les établissements d'enseignement supérieur en Tanzanie : une perspective historique., 24(3), 127-144. Retrieved from http://search.ebscohost.com/login.aspx?direct=true \&db=aph\&AN=95000326\&site=ehost-live

Nwajiuba, C. A., Igwe, P. A., Akinsola-Obatolu, A. D., Ituma, A., \& Binuomote, M. O. (2020). What can be done to improve higher education quality and graduate employability in Nigeria? A stakeholder approach. Industry and Higher Education. doi:10.1177/0950422219901102

Schomburg, H., \& Teichler, U. (2006). Higher Education and Graduate Employment in Europe: Results from Graduate Surveys from Twelve Countries. Dordrecht: Springer.

Sifuna, D. N. (1998). The governance of Kenyan public universities. Research in Post-Compulsory Education, 3(2), 175-212. doi:10.1080/13596749800200030

Stiwne, E. E., \& Alves, M. G. (2010). Higher Education and Employability of Graduates: Will Bologna Make a Difference? European Educational Research Journal, 9(1), 32-44. doi:10.2304/eerj.2010.9.1.32

Teichler, U., \& Jung, J. (2016). Graduate Employment and Higher Education in Asia: Introduction to a Special Issue of International Journal of Chinese Education. International Journal of Chinese Education, 5, 123-134.

The Controller and Auditor General, C. (2019). Report of the Controller and Auditor General on the Audit of Financial Statements of Tanzania Commission for Universities for the Financial Year Ended 30th June, 2018. In The United Republic of Tanzania, National Audit Office.

The United Republic of Tanzania, U. (1999). National Higher Education Policy. Dar es Salaam

United Republic of Tanzania, U. (2008). National Employment Policy. In E. a. Y. D. Labour (Ed.). Dar es Salaam.

Vavrus, F. (2005). Higher Education in Tanzania: a case study. Africa (Edinburgh University Press), 75(2), $263-$ 264. doi:10.3366/afr.2005.75.2.263

Vincent, S. A., \& Robert, N. K. (2019). The Employability Status of Makerere University Graduates. Journal of Education and Practice, 10(6). doi:10.7176/jep

Yorke, M. (2004). Employability in the Undergraduate Curriculum: Some Student Perspectives. European Journal of Education, 39(4), 409-427. Retrieved from www.jstor.org/stable/1503868

Yorke, M. (2006). Employability in Higher Education: What It Is, What It Is Not. In P. M. Yorke. (Ed.), Learning and Employability Series 1 and 2: Higher Education Academy (LTSN) and Enhancing Student Employability Co-ordination Team (ESECT). 